\title{
of Law and Religion
}

Volume XX

Number 2

2004-2005

\section{Articles}

A Forerunner for International Organizations: The Holy See and the Community of Christendom-with Special Emphasis on the Medieval Papacy

Robert John Araujo John A. Lucal

Anver M. Emon

Natural Law and Natural Rights in Islamic Law

German Courts Decide Who is Jewish: On the Agreements Between the German State and Jewish Groups, and the Resulting Litigation

Greg Taylor

Rawls's Dangerous Idea?: Liberalism, Evolution and the Legal Requirement of Religious Neutrality in Public Schools

Francis J. Beckwith

A Dream Dialogue on Religious Liberty

Frederick W. Guyette

A Brief Survey and Critique of the Case Against the Use of Religious Arguments in the United States

Albert A. Starkus III

Truth Commissions and Transitional Justice: Update on a Select Bibliography on the South African Truth and Reconciliation Commission Debate

\section{Book Reviews}

Religion and the Rise of Jim Crow in New Orleans, by James B. Bennett

Alfred L. Brophy

Ideas and the Man: Remembering David Daube, by Calum Carmichael

Charles J. Reid, Jr 
Sponsored by: Hamline University School of Law

Published by: Hamline University School of Law ISSN: 0748-0814 


\section{THE JOURNAL OF LAW AND RELIGION}

\section{EDITORIAL STAFF}

\section{Editor}

MARIE A. FAILINGER, Hamline University School of Law

\section{Associate Editors}

PATRICK KEIFERT, Luther Theological Seminary

HOWARD J. VOGEL, Hamline University School of Law

\section{Book Review Editor}

LESLIE GRIFFIN, University of Houston Law Center

\section{Technical Editors}

MARY L. DUNNEWOLD, Hamline University School of Law STEPHEN LIEBO, Hamline University School of Law

\section{Production/Subscription Manager}

LiNDA BERgLIN, Hamline University School of Law

ANDREA COBERY

REBECCA PINERo

\section{EDITORIAL ASSISTANTS}

Christopher GANGLE

JOHN SADOWSKI
PETER NAVIS

LINDSAY SHAW

\section{EDITORIAL BOARD}

ELIZABETH MENSCH, State University of New York at Buffalo, School of Law, Chair AZIZAH AL-HIBRI, T.C. Williams School of Law, University of Richmond

STEPHEN L. CARTER, Yale Law School

PAULA COOEY, Macalester College

ANTHONY E. COOK, Georgetown University Law Center

MARIE FAILINGER, Hamline University School of Law Ex Officio

JON M. GARON, Hamline University School of Law

LESLIE C. GRIFFIN, University of Houston Law Center

$$
\text { Ex Officio }
$$

EMILY ALBRINK HARTIGAN, Saint Mary's University of San Antonio School of Law AFRA JALABI, Islamic Scholar, Ile Perrot, Quebec

JOSE ROBERTO JUAREZ, Saint Mary's University of San Antonio School of Law

PATRICK R. KEIFERT, Luther Theological Seminary HOWARD LESNICK, University of Pennsylvania Law School 
ROBIN LOVIN, Perkins School of Theology, Southern Methodist University NANCY MILLER-HERRON, Attorney at Law, Dresden, Tennessee, Secretary THOMAS PORTER, JUSTPEACE Center for Mediation \& Conflict Transformation

RICHARD QUINNEY, Professor Emeritus, Northern Illinois University EARL SCHWARTZ, Hamline University

DARRYL TRIMIEW, Colgate Rochester Crozer Divinity School AMELIA UELMEN, Fordham University School of Law HOWARD J. VOGEL, Hamline University School of Law, Treasurer 


\section{ADVISORY COMMITTEE}

TAHA JABER AL-ALWANI, Graduate School of Social and Islamic Sciences ZAFAR ISHAQ ANSARI, Islamic Research Institute, International Islamic University, Pakistan

RICHARD BAEPLER, Professor Emeritus, Valparaiso University School of Law MILNER BALL, University of Georgia School of Law HAROLD BERMAN, Emory University School of Law GERARD BRADLEY, Notre Dame University Law School MICHAEL J. BROYDE, Emory University School of Law LYNN BUZZARD, Campbell University School of Law

FRED CARNEY, Professor Emeritus, Perkins School of Theology, Southern Methodist University

ROBERT F. COCHRAN, JR., Pepperdine University School of Law MOHAMED S. EL-AWA, Islamic Scholar, Egypt

CARL ESBECK, University of Missouri-Columbia School of Law EDWARD MCGLYNN GAFFNEY, JR., Valparaiso University School of Law

RICHARD HIERS, University of Florida

CATHLEEN KAVENY, Notre Dame University Law School

DAMIEN KEOWN, University of London, Goldsmiths

SANFORD LEVINSON, University of Texas School of Law

DAVID LITTLE, Harvard University Divinity School

SEYYED HOSSEIN NASR, George Washington University LOUIS NEWMAN, Carleton College

MICHAEL PERRY, Emory University School of Law

KAY PRANIS, Saint Paul, Minnesota

ELISABETH SCHÜSSLER FIORENZA, Harvard University Divinity School

THOMAS L. SHAFFER, Notre Dame University Law School

DOUGLAS STURM, Professor Emeritus, Bucknell University

PETER N. THOMPSON, Hamline University School of Law

CHARLES VILLA-VICENCIO, Institute for Justice and Reconciliation, South Africa

MICHAEL WELKER, University of Heidelberg, Germany

JOHN WITTE, Jr., Emory University School of Law

WILSON YATES, United Theological Seminary of the Twin Cities

STEPHEN B. YOUNG, Attorney at Law, Saint Paul, Minnesota 
The Journal of Law and Religion is sponsored by the Hamline University School of Law and is a interdisciplinary, interfaith academic and professional publication devoted to investigating the interaction of religion and law.

Subscriptions to the Journal of Law and Religion, which is published twice annually, are $\$ 25$ per two-issue volume for individuals, $\$ 35$ for institutions, and $\$ 10$ for students. Add an additional $\$ 10$ for foreign postage. Subscription requests, manuscripts, and general correspondence should be addressed to:

\author{
Journal of Law and Religion \\ 1536 Hewitt Avenue \\ Saint Paul, Minnesota 55104 \\ lberglin@hamline.edu
}

Book reviews and books to be reviewed should be addressed to: lgriffin@uh.edu

Citations generally conform to the Association of Legal Writing Directors' ALWD Citation Manual. Citations to Jewish/Christian Biblical sources conform to the SBL Handbook of Style and the Jewish Law Annual. Unsolicited manuscripts will be returned only upon request.

Individual and back issues and complete sets of the Journal of Law and Religion may be ordered directly from William S. Hein \& Co., 1285 Main Street, Buffalo, New York 14209.

The views and opinions expressed in the Journal of Law and Religion are those of the authors and do not necessarily reflect the views of the editorial staff, the editorial board, the advisory board, or the sponsors of the Journal of Law and Religion.

Articles are indexed in the Index to Legal Periodicals published by the H.W. Wilson Co. (Bronx, New York), and in the Legal Resource Index available on-line on a variety of computer database services.

Articles are also indexed in Religion Index One: Periodicals; book reviews are indexed in Index to Book Reviews in Religion. Both indexes are published by the American Theological Library Association, Chicago, and are available online through BRS Information Technologies (Latham, New York) and DIALOG Information Services (Palo Alto, California).

Internet access to information about the Journal of Law and Religion, including an index to past issues, is available at http://www.hamline.edu/law/jlr

All copyrights are reserved.

Cite as: 20 J. L. \& ReLIG. (2004-05) 


\section{JOURNAL OF LAW AND RELIGION}

\section{STATEMENT OF PERSPECTIVE}

The Journal of Law and Religion was initiated in 1982 as a collaborative effort of the Council on Religion and Law and the Hamline University School of Law. It was born of a sense of historical malaise. The modern age with its strong propensity toward the secularization of all areas of life, while not without merit in its liberating effects, nonetheless has its dark side.

We live, some say, in a time of profound historical crisis. Domestically and globally, we confront massive issues which force us to reconsider, in fundamental ways, the shape and quality of our common life. Yet many of the disciplines of thought and practice that should be a rich resource in such a time are found wanting-among them, law and religion. Law, a discipline presumably devoted to the ways of justice, has all too often become a set of complex, technical tools without concern for higher purpose. Religion, presumably given to the all-embracing promises and prescriptions implied in the sense of the sacred, has all too often become privatized and neglectful of our public life.

The Journal of Law and Religion is dedicated to a fundamental reappraisal of the disciplines of law and religion as they impinge on each other, might instruct each other, and taken in their conjunction, might offer a constructive response to the major issues of our times. As such its concerns are sixfold.

Historical The Joumal intends to encourage the examination of historical developments, movements, thinkers, and issues to enrich our understanding of how law and religion have, in various ways, been mutually influential.

Theoretical The Journal intends to promote constructive work in religious and legal thought about fundamental theological and jurisprudential questions pertaining to professional practice and the structures of our public life.

Ethical The Journal intends to support explorations into the foundations of ethical judgment and normative critiques of our social life, particularly as they draw upon resources from the life of law and religion.

Global The Joumal intends to be encompassing in its reach, seeking out voices from all the religious and legal traditions throughout the world and bringing them into conversations with each other.

Professional The Journal intends to stimulate collaboration between jurists and religious leaders given their respective commitments, as professionals, to the common good of all peoples.

Spiritual The Journal recognizes that human existence is grounded in the spiritual, which is represented in many forms and expressions.

The Journal is thus a forum within which the disciplines of law and religion might together consider with utmost seriousness their joint responsibility for the creation of a civilization of genuine peace and justice. Within the compass of that purpose, the Journal intends to be open-minded and non-prejudicial; it is receptive to submissions from all persuasions and perspectives. 


\section{HAMLINE \\ UN I V E R S I T Y \\ SCHOOL OF LAW}

\section{A subscription to the \\ JOURNAL OF LAW AND \\ RELIGION}

Cost per volume (two issues):

$\$ 25.00$ individual (U.S.)

$\$ 35.00$ individual (foreign)

$\$ 35.00$ institution (U.S.)

$\$ 45.00$ institution (foreign)

$\$ 10.00$ student

Circulation Manager

Journal of Law and Religion

Hamline University School of Law

1536 Hewitt Avenue

St. Paul, MN 55104

U.S.

\section{Payment Enclosed}

Name:

Address:

City:

State:

Zip:

Country:

Phone:

Fax:

E-Mail: 


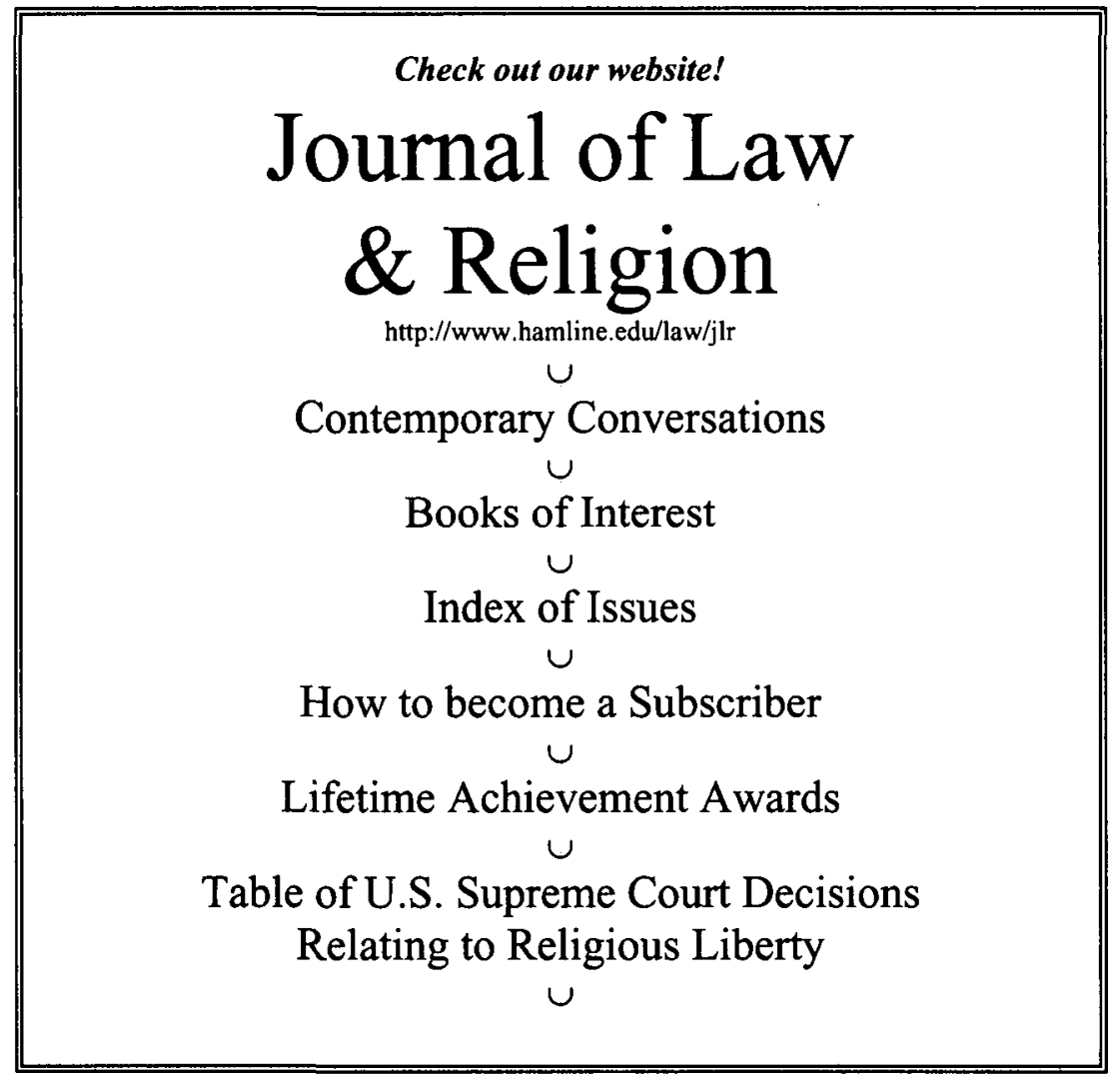




\title{
ANNOUNCEMENT
}

We have acquired the entire back stock, reprint and microform rights to the

\section{JOURNAL OF LAW AND RELIGION}

Complete sets to date are now available. We can also furnish single volumes and issues.

\author{
WILLIAM S. HEIN \& COMPANY, INC. \\ 1285 Main Street \\ Buffalo, New York 14209
}




\section{O L U M B I A, Refer to us}

columbia.edu/cu/cup

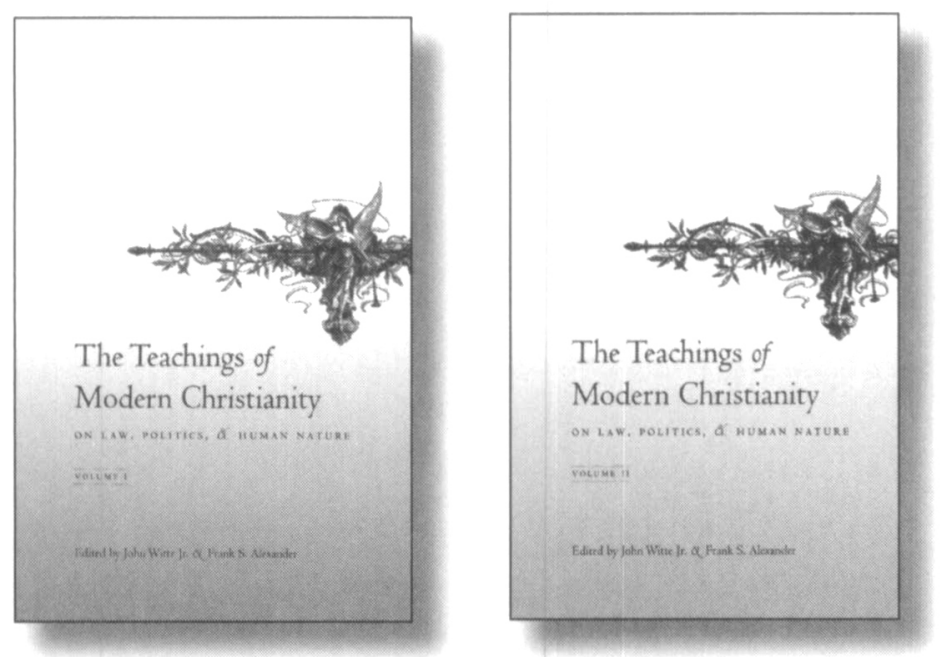

\section{The Teachings of Modern Christianity on Law, Politics, and Human Nature}

\section{Edited by John Witte \& Frank Alexander}

"These twin volumes are destined to become standard texts of modern Christian legal and political theory. Rarely have the riches of modern theology and theological anthropology been so incisively analyzed for their insights into the fundamentals of our modern political condition."

-Jean Bethke Elshtain, University of Chicago

Vol I: cloth $-\$ 75.00$

Vol II: cloth - \$75.00 


\section{THE JOURNAL OF LAW AND RELIGION}

\section{TABLE OF CONTENTS}

Editor's Preface xiii

\section{ARTICLES}

Robert John Araujo John A. Lucal

Anver M. Emon

A Forerunner for International Organizations:

The Holy See and the Community of

Christendom-with Special Emphasis on the

Medieval Papacy.

Natural Law and Natural Rights in Islamic Law.

Greg Taylor

German Courts Decide Who is Jewish:

On the Agreements Between the German State and Jewish Groups, and the Resulting Litigation.

Francis J. Beckwith Rawls's Dangerous Idea?: Liberalism, Evolution and the Legal Requirement of Religious Neutrality in Public Schools.

Frederick W. Guyette A Dream Dialogue on Religious Liberty 459

Albert A. Starkus III

A Brief Survey and Critique of the Case Against the Use of Religious Arguments in the United States. 
JOURNAL OF LAW \& RELIGION

Karin Alexander

Diana Batchelor

Alexis Durand

Tyrone Savage

Truth Commissions and Transitional Justice:

Update on a Select Bibliography on the

South African Truth and Reconciliation

Commission Debate

\section{BOOK REVIEWS}

Alfred L. Brophy Religion and the Rise of Jim Crow in New Orleans,

by James B. Bennett.

Charles J. Reid, Jr. Ideas and the Man: Remembering

David Daube,

by Calum Carmichael

Christopher C. Lund The Freedom of Faith-Based Organizations

to Staff on a Religious Basis,

by Carl H. Esbeck, Stanley W. Carlson-

Thies, and Ronald J. Sider

Christopher C. Lund Does God Belong in the Public Schools?, by Kent Greenawalt

Paul Weithman Putting Liberalism in its Place, by Paul W. Kahn 